\title{
Chronic Lower Abdominal Pain After the Insertion of the Second Intrauterine Device
}

\author{
ikinci Rahimiçi Araç Uygulaması Sonrası Gelișen Kronik Alt Karın Ağrısı
}

\author{
Kahraman Ülker', Abdülaziz Gül', İsmail Temur1, Mustafa Ersöz¹, İslim Volkan1, Mehmet Karaca² \\ ${ }^{1}$ Kafkeas University School of Medicine, Obstetrics and Gynecology, Kars, Turkey, ${ }^{2}$ Antalya Educational and Research Hospital, Obstetrics and \\ Gynecology, Antalya, Turkey
}

\begin{abstract}
The planned insertion of a second intrauterine device prior to the tracing of and management of a lost, dislocated or intra abdominally migrated device is a subject which has not been broached in the literature. Moreover, neither the insertion of a second intrauterine device in addition to an existing one or the co-insertion of two devices at the same time has ever, to our knowledge, been reported previously in the literature. In this report, we aim to present the co-existence of two intrauterine devices in a woman who had been suffering from chronic lower abdominal pain. A national patient record system and close adherence to the available guides will improve the quality of the family planning services while decreasing complication rates.
\end{abstract}

Key words: abdominal pain; contraceptive IUD; family planning services; IUD migration; personal health records

\section{ÖZET}

Atılan, kayan ya da karın içine geçen rahimiçi araç çıkarılmadan ya da sağaltımı yapılmadan ikinci bir rahimiçi aracın planlı uygulanması literatürde görülmemektedir. Dahası, bizim bilgimize göre, var olan rahimiçi araca ek olarak ikinci bir aracın uygulanması ya da aynı anda iki rahimiçi aracın uygulanması daha önce hiç bildirilmemiștir. Bu yazıda, kronik alt karın ağrısı olan bir kadında aynı anda var olan iki adet rahimiçi aracı sunmayı amaçladık. Ulusal hasta kayıt sistemi ve varolan rehberlerin yakın takibi aile planlaması hizmetlerinin kalitesini arttıırken, komplikasyon oranlarını düșürecektir.

Anahtar kelimeler: karın ağrısı; gebelik önleyici ajanlar, rahim içi; aile planlaması hizmetleri; RiA yer değișimi; sağlık kayıtları, personel

With its highly accepted efficacy and safety, the intrauterine device (IUD) is the most widely used reversible contraceptive method. The addition of copper or a levonorgestrel releasing system has increased its efficacy in current usage ${ }^{1}$.

Kahraman Ülker, Kafkas Üniversitesi T⿰p Fakültesi Kadnn Hastahklarn ve Doğum Anabilim Dal, Kars, Türkiye, Tel. 05055700574 Email. kabramanulker@hotmail.com

Geliş Taribi: 07.08.2011 • Kabul Taribi: 13.08.2011
Increased menstrual bleeding and dysmenorrhea are the most common reasons for IUD removal ${ }^{2}$. Device expulsion with subsequent pregnancy and the migration of the device into the intra-peritoneal and the retroperitoneal tissues following a uterine perforation are major complications involved with the use of this device ${ }^{1-5}$.

The planned insertion of a second IUD prior to the tracing of and management of a lost, dislocated or intra abdominally migrated IUD is a subject which has not been broached in the literature. Moreover, neither the insertion of a second IUD in addition to an existing IUD or the co-insertion of two IUDs at the same time has ever, to our knowledge, been reported previously in the literature. In this report, we aim to present the co-existence of two IUDs in a woman who had been suffering from chronic lower abdominal pain.

\section{Case}

A 44-year-old woman presented herself to our department with a history of bilateral lower abdominal pain. This pain had started six months earlier, following the insertion of an IUD. The constant pain became sharper and more severe during menstruation. A further factor affecting her discomfort was that analgesics were ineffective in pain relief.

The woman had delivered three children 23, 14 and 8 years ago, respectively. She had used IUDs between her births. Following the birth of the third child, she again began to use a new IUD, which she used for eight years. One year ago, the IUD was removed for the intention of "uterine rest" by a gynecologist working in the private sector. Besides the removal, she neither received a follow-up consultation, nor was she offered an alternative contraceptive method. 

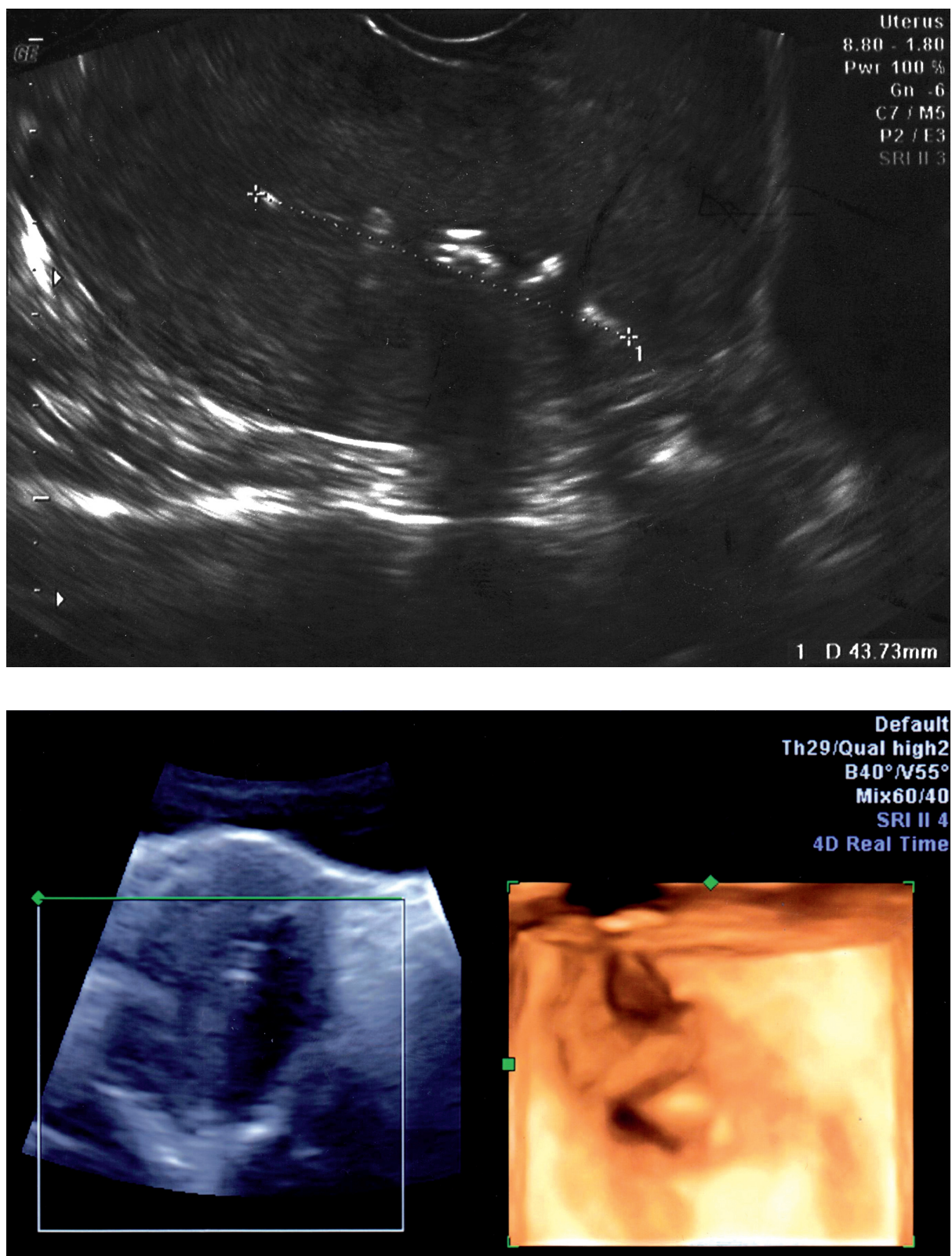

Figure 1. Trans-perineal and trans-vaginal ultrasound examinations revealed an opaque image resembling an IUD in the endometrial cavity. However, the opaque image was continuous from the upper pole of the uterine fundus into the cervical canal, with some fragmentations in its course.
Six months after the removal of the IUD, she again elected to have another IUD fitted due to concerns about an unwanted pregnancy. However, she has suffered from a bilateral lower abdominal and groin pain since the insertion of the last IUD.

During the examination, the string of the IUD was observed in the endo-cervical canal. Cervical and uterine palpation and movements were painful. Other findings were unremarkable.

Trans-perineal and vaginal ultrasound examinations revealed an opaque image resembling an IUD in the endometrial cavity. However, the opaque image was continuous from the upper pole of the uterine fundus into the cervical canal, with some fragmentations in its course (Figure 1). This extension of the opaque image brought us to consider the possibility of a co-existing endometrial pathology, foreign body, or a fragmented IUD.

Although we did obtain an image compatible with two separate fragments of an IUD or two separate complete IUDs during the three dimensional ultrasound examinations, we were unable to prove either (Figure 2). However we determined two crossing 


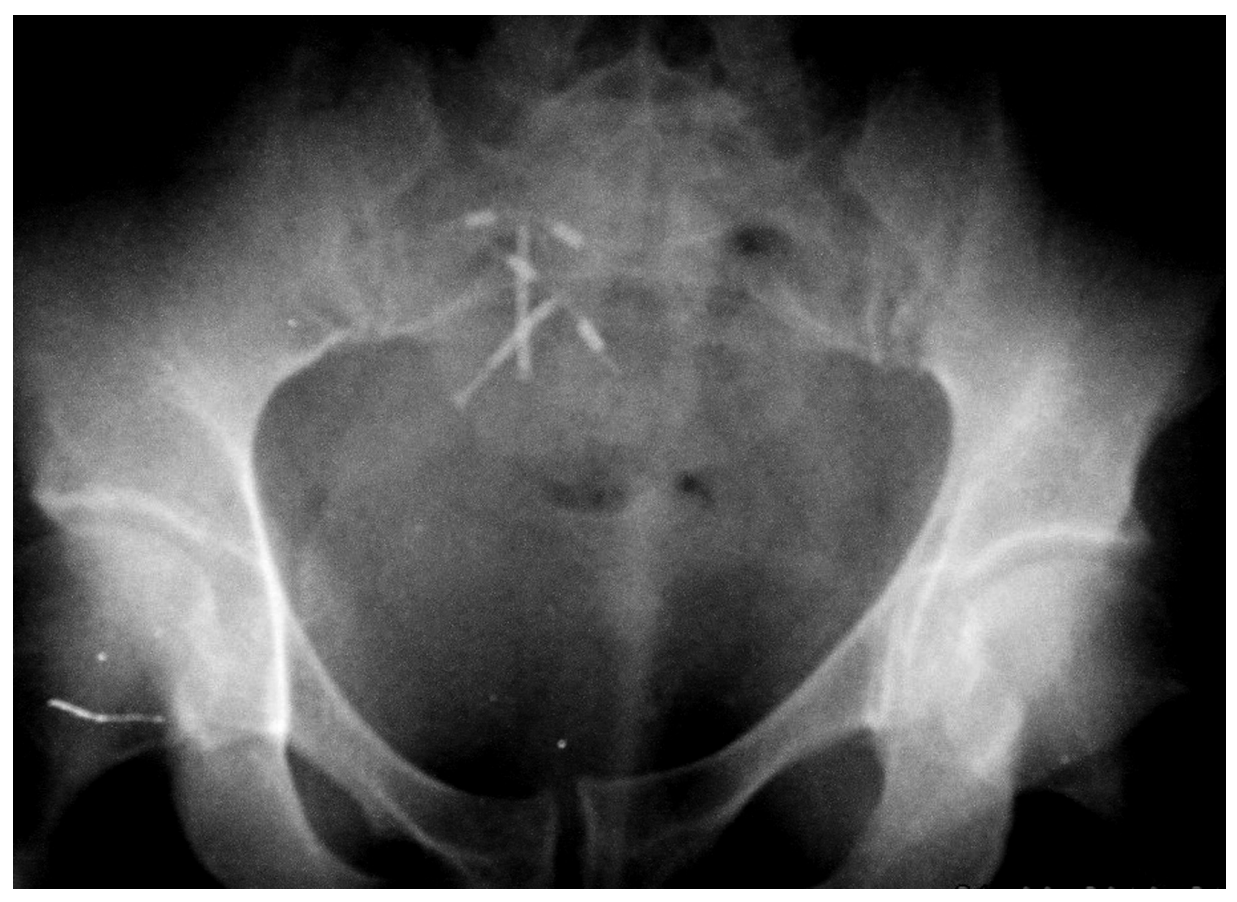

Figure 3. Two crossing IUDs in the uterine cavity in the $X$-ray examination of the pelvis and the uterus.

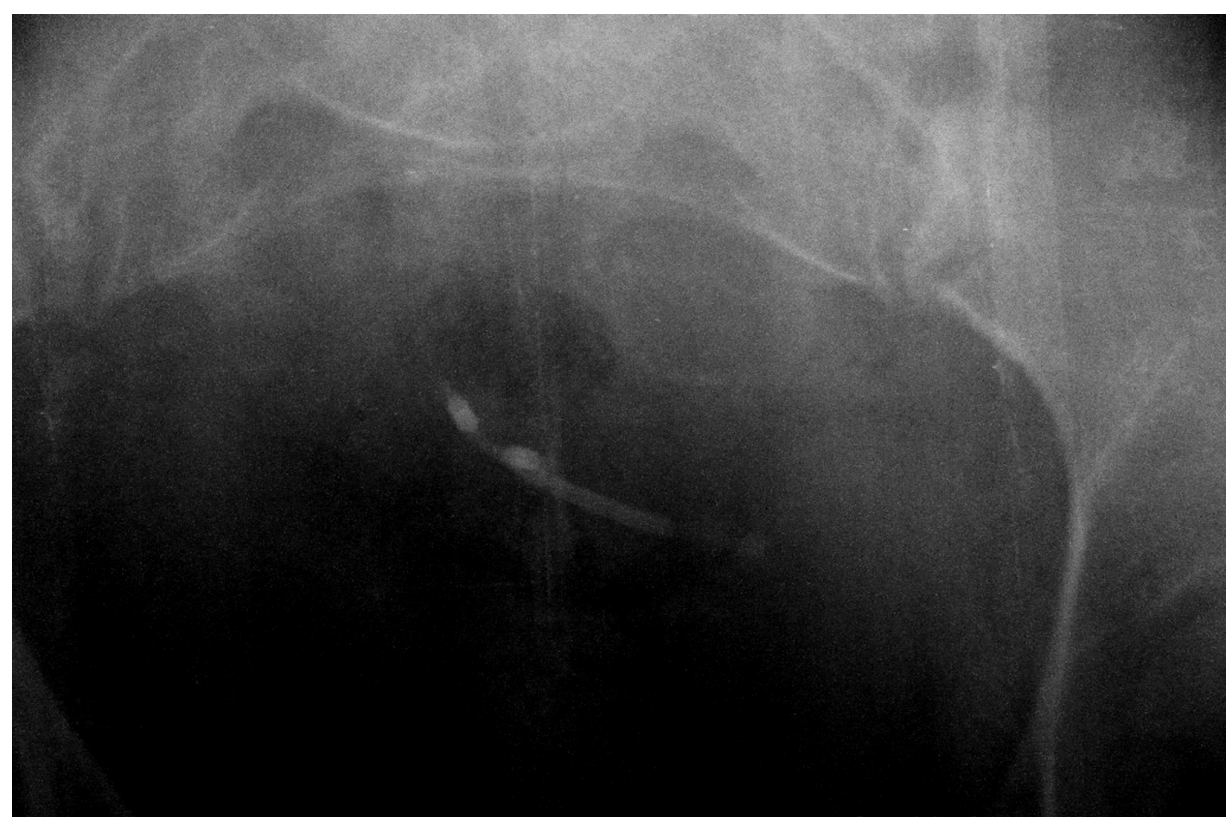

Figure 4. The remaining IUD was observed to be in the regular position following the removal of the second-extra IUD.

IUDs in the uterine cavity in the pelvic X-ray examination (Figure 3).

The woman elected for the removal of one of the IUDs. We decided to remove the IUD which had visible strings from the cervical canal, and left the IUD which had lost its strings in the uterine cavity to provide further contraception (Figure 4). The remaining IUD was observed to be in the regular position following the procedure.
The woman insisted that her private specialist had indeed removed the previous IUD. During her followup visits, she was free of symptoms and the IUD has been determined to be in the normal position for the last six months.

\section{Discussion}

Coexistence of an intra or extra uterine pregnancy, pelvic inflammatory disease, and uterine perforation 
are the most serious complications of IUD use. In addition, pain during the insertion and the removal of an IUD, an increase in menstrual bleeding, abdominal and groin pain, dysmenorrhea, and dislocation or expulsion of the device are other unwanted effects ${ }^{6}$.

Information pertaining to the migration of an IUD into the abdominal tissues following a perforation of the uterine wall and subsequent health problems related with this has been previously published ${ }^{1-5}$. In some of these cases, an inability to detect the IUD in the uterine cavity has led to the conclusion that the IUD had been expelled, and, thus, resulted in the insertion of a second IUD. To our knowledge, the insertion of two IUDs into the same uterine cavity simultaneously has not been previously reported. In addition, the application of more than one IUD insertion in order to increase contraceptive efficacy has never been performed.

Both the World Health Organization and many individual countries publish guidelines to help increase the quality of family planning services. Close observance to these guides helps raise contraceptive efficacy and also reduce unwanted side effects ${ }^{6-8}$. Adherence to these guides helps service receivers to choose the most appropriate contraceptive method for themselves after first understanding the characteristics and the possible outcomes of using a particular contraceptive method. Contraceptive providers will also benefit by achieving standardization in family planning services.

Turkey also has a national guide of family planning services and contraceptive use prepared by the Turkish Ministry of Health ${ }^{6,9}$. Use of the national family planning guide could possibly have helped prevent the unnecessary insertion of the second IUD in our case.

Sources of information concerning the alternative contraceptive methods available can generally be obtained from family planning centers, maternity or general health hospitals, private offices, the media, the internet or current/ previous users of any given contraception. However, both the positive and negative sides of these contraceptive alternatives should be explained during their presentation. This ensures that the women seeking advice receive the opportunity to make an objective selection, which in turn, increases efficacy while decreasing unwanted side effects $^{10,11}$. In our case the woman was not advised on the alternative contraceptive methods available to her. Perhaps her previous specialist was unable to locate and remove the IUD, and without the assistance of any imaging modality reached the conclusion that the IUD had indeed been expelled. However, the physician should have informed the patient about the outcome of the IUD.

One of the most important parts of the family planning services, as in any other medical practical procedure, is the patient record system. The aim of taking records is to collect data to use in future services in order to improve the quality and the scientific value of the services, ${ }^{9,13}$. In our case, the lack of a record, or a record system, was one of the sources of the error occurring. A national patient record system incorporating patient records taken in hospitals, private health centers, and private offices may help in error detection and prevent complications. One means of minimizing errors could be to provide computer based accessibility to patient records or to such patient-handled records as patient cards to all health providers.

We believe that the lack of a patient record system accessible to all health providers as well as the lack of service standardization caused the insertion of the second IUD while the first IUD was still in the uterus.

As a conclusion, a national patient record system and close adherence to the available guides will improve the quality of the family planning services while decreasing complication rates. To improve health providers' adherence to the guides, standardized and updated educational programs are needed.

\section{References}

1. The ESHRE Capri Workshop Group. Intrauterine devices and intrauterine systems. Human Reproduction Update 2008; 14:197-208.

2. Hubacher D, Chen PL, Park S. Side effects from the copper IUD: do they decrease over time? Contraception 2009; 79: 356-62. doi:10.1016/j.contraception.2008.11.012.

3. Gillis E, Chhiv N, Kang S, Sayegh R, et al. Case of Urethral Foreign Body: IUD Perforation of the Bladder with Calculus Formation. Cal J Emerg Med 2006; 7:47-53.

4. Delotte J, Trastour C, Bafghi A, et al. Un motif de consultation surprenant: la perception de fils sortant par l'anus, a propos d'une complication rare de la pose de DIU (A surprising reason for consulting: wires projecting from the anus, a rare complication of intra uterine device insertion) [Article in French]. J Gynecol Obstet Biol Reprod 2006; 35:820-1. 
5. Chang HM, Chen TW, Hsieh CB, et al. Intrauterine contraceptive device appendicitis: a case report. World J Gastroenterol 2005; 11:5414-5.

6. Turkish Republic Health Ministry Directorate of Maternity, Child Health and Family Planning. National family planning service guide volume 1. Contraceptive methods [Turkish]. Ankara: Damla Matbaacilık, 2005.

7. Centers for Disease Control and Prevention (CDC). U S. Medical Eligibility Criteria for Contraceptive Use, 2010. MMWR Recomm Rep 2010; 59:1-86

8. Yazdi NA, Tavafian SS, Emadzadeh A, et al. Communication training and patient satisfaction: A randomized trial study from Mashhad, Iran. Patient Prefer and Adherence 2008; 2:137142.

9. Turkish Republic Health Ministry Directorate of Maternity, Child Health and Family Planning. National Family Planning Services Guide Volume 1. Family Planning and Reproductive Health [Turkish]. Damla Matbaacilık, Reklamcilık ve Yayıncılık Tic.Ltd.Şt. Ankara, 2005.

10. Khan MA. Factors associated with oral contraceptive discontinuation in rural Bangladesh. Health Policy Plan. 2003; 18: 101-8.

11. Estrada F, Hernández-Girón C, Walker D, et al. Use of family planning services and its relationship with women's decisionmaking and support from their partner. [Article in Spanish] Salud Publica Mex. 2008; 50: 472-81.

12. Finney JM, Walker AS, Peto TE, et al. An efficient record linkage scheme using graphical analysis for identifier error detection. BMC Med Inform Decis Mak 2011; 11:7.

13. Staggers N, Weir C, Phansalkar S. Patient Safety and Health Information Technology: Role of the Electronic Health Record. In: Hughes RG, editor. Patient Safety and Quality: An Evidence-Based Handbook for Nurses. AHRQ Publication 2008: 92-133. 